\title{
Development of Cloud-Based Co-Parenting Strengthening System
}

\author{
Mychael Maoeretz Engel ${ }^{1}$, Jenny Lukito Setiawan ${ }^{2}$, Lisa Indriati ${ }^{3}$ \\ ${ }^{1}$ School of Information Technology, Universitas Ciputra Surabaya, Indonesia, \\ ${ }^{2}$ School of Psychology, Center for Marriages and Families, Universitas Ciputra Surabaya, Indonesia \\ ${ }^{3}$ School of Creative Industry, Universitas Ciputra Surabaya, Indonesia

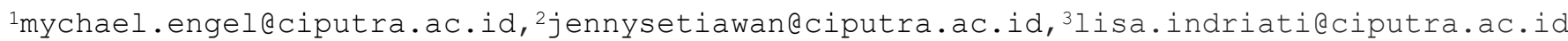

\begin{abstract}
Co-parenting emphasizes how couple manage their relationship in the parenting domains and carry out their role as parents. Based on research conducted by Feinberg and colleagues (2012), there are four overlapping domains of co-parenting: (1) child rearing agreement; (2) support/undermining partner's parenting; (3) joint family management; and (4) division of labor. The interference of cloud-based and mobile technology is needed on the coparenting relationship between the couple with reference to the four domains of co-parenting. The method used was the Systems Development Life Cycle (SDLC) model. It was divided into six stages of the process: requirement analysis, system design, implementation, system testing, system deployment, and system maintenance. In implementation, the cloud-based co-parenting strengthening system at an early stage has four main features: (1) child's activity scheduling and reminder; (2) co-parenting's education contents; (3) partner's feedback; and (4) co-parenting's assessment. The results that are proven by experts, agreed that educational content in the application is very necessary for more knowledge for parents, UI/UX design that is friendly and easy to understand by users, as well as the use of the latest reliable and flexible technology.
\end{abstract}

Keywords: co-parenting, strengthening system, cloudbased, mobile technology

\section{INTRODUCTION}

The Indonesian government believes that the aspiration to create a cultured and characterized Indonesian nation can be achieved through education, parenting, habituation and exemplary in the family. Family plays an important role in inculcating moral values and character for the younger generation of the nation's successors, so it is also necessary to understand the family in the pattern of parenting and mentoring children from an early age. In achieving this, it is not enough just to improve parenting among parents in Indonesia. However, good cooperation is needed in coparenting between the two parents [1].
Co-parenting emphasizes how couple manage their relationship in the parenting domains and carry out their role as parents [2-3]. In other word, coparenting also deals with the cooperation between mother and father in their endeavors to parent their children. Based on research conducted by Feinberg [3-4] there are four overlapping domains of co-parenting: (1) child rearing agreement; (2) support/undermining partner's parenting; (3) joint family management; and (4) division of labor. Child rearing agreement focuses on parents' agreement about child-related topics, such as education, discipline, health care, priorities, moral value, etc. Support/undermining partner's parenting relates to how parents support or undermine each other's role as a parent. Joint family management is concerned on how parents manage relationship conflicts by considering the child. Lastly, division of labor is how parents share the responsibilities related to child.

Personal communication between couple is an important key to co-parenting solidarity. It is hard to build a good cooperation if someone does not trust the ability and capacity of his partner in co-parenting [5]. So, to avoid things that trigger feelings of distrust towards partner, a communication medium is needed where couples can monitor each other, schedule, organize, and give affirmation and appreciation to their partners in undergoing co-parenting. Communication media in the form of web-based and mobile-based chat applications are now often used by couples in co-parenting, but this is considered not yet able to accommodate all the needs of co-parenting.

The development of information technology, especially smartphone devices with the support of high mobility and coupled with the online which is growing every second, has proven to be able to help humans to solve problems faster in every sector of life. The application of technology in the form of web and mobile applications has been used in the manufacture of multimedia-based educational applications to support 
early childhood learning [6], assessment applications for Tuberculosis sufferers [7], and many more. The role of technology has now touched the field of social life, where the areas of psychology and counseling are included. Chatbot applications for counseling people with HIV/AIDS [8], online counseling guidance services between teachers and students at schools [9], application of website-based counseling logos [10], health applications of genetic counseling for women with ovarian cancer [11] are real examples application of technology in the world of psychology and counseling.

In the world of parenting, technological intervention itself has a positive effect on parenting and emotional well-being of parents with children [12], and is an effective alternative even though they are not intensely met in person [13]. This statement is further strengthened by the application of the e-parenting consulting application which is an educational solution and consultation for parents and Early Childhood Education (PAUD) institutions in West Nusa Tenggara [14].

This study focuses on the interference of mobilebased technology on the co-parenting relationship between the couple with reference to the four domains of co-parenting. The implementation of the features in the mobile application that will be developed are assessment and supports media of the four domains of co-parenting.

\section{METHOD}

The method that used in this research is Systems Development Life Cycle (SDLC) model or better known as the Waterfall Model. Systems Development Life Cycle model is divided to six stages: (1) requirement analysis; (2) system design; (3) implementation; (4) system testing; (5) system deployment; (6) system maintenance [15]. Systems Development Life Cycle can be seen in Fig. 1.

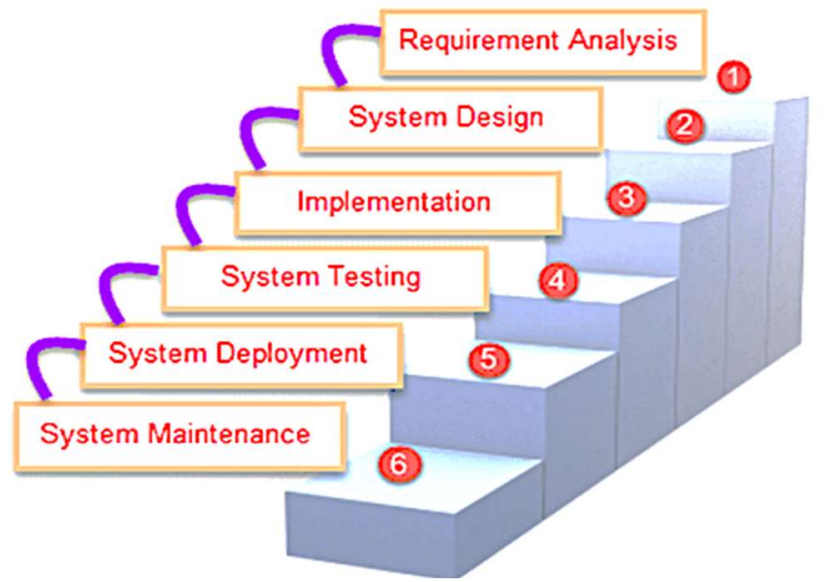

Fig. 1 Systems development life cycle (SDLC) model [15]

\section{A. Requirement Analysis}

Data collection techniques used to analyze user needs are interviews in the form of focus group discussions with 30 respondents consisting of married couples and divided into four age categories of children owned, namely toddlers, elementary school, junior high school and high school. The interview stages started from: (1) an explanation of co-parenting and the four domains of co-parenting; (2) asking questions that refer to the four domains of co-parenting; (3) discuss the feature needs of married couples that will be implemented in the mobile application.

\section{B. System Design}

The system design represents workflow, management, and programming to develop the information system. At this stage, the design of co-parenting Strengthening system will be made using an overview of suggested system model.

\section{Implementation}

At this stage, the cloud-based co-parenting strengthening system will be implemented. There are three main modules of application:

1) Admin's Web Application: Admin's web application will be built with CodeIgniter (CI), which is a powerful PHP framework with a very small footprint and has a model-view-controller (MVC) base [16]. The model contains a class or function create, update, delete, retrieve in a database. View is part of the user interface (UI) that will be seen by the user. Controller is a management class and a link between the model and the view [17-18].

2) Web API: Application Programming Interface (API) is a software intermediary that allows two or more applications communicate each other. Web API will be built using CodeIgniter's restful API [16] which will allow the user's mobile application and the admin's web application to be well integrated.

3) User's Mobile Application: User's mobile application will be built using Flutter which is a crossplatform framework developed by Google [19]. Flutter is Google's UI toolkit for building beautiful, natively compiled applications for mobile (android and iOS), web, desktop, and embedded devices from a single codebase [20-21].

\section{System Testing}

The system testing is divided to two steps, named alpha testing and beta testing. In alpha testing, the method used is black-box testing which the test focuses 
on the functional specifications of the application [22]. The test cases are important features like register, login, match the parent, scheduling, reminder, and showing the contents of education. Tester can define a set of input scheme and test the functional specifications in the application. Then, beta testing will be done by the users outside the system developer. In this stage, we carried out a limited testing of 3 experts from the fields of psychology, UI/UX design and technology as respondents to try all the features in the mobile application and interviewed them about for feedbacks that covers the usability and benefits of the system that had been developed.

\section{E. System Deployment}

In this stage, application will be distributed to the targeted married couples that have child to help them in undergoing co-parenting.

\section{F. System Maintenance}

The system maintenance process of cloud-based coparenting strengthening system will be happen if there are features update and IT infrastructures improvement.

\section{RESULTS AND DISCUSSION}

Based on the results of interviews that have been conducted from requirement analysis stage, it was found that chat applications in general so far cannot accommodate all parenting needs. After processing and analyzing the data from the couple's needs, it was finally found that some of the features needed in the development of a co-parenting strengthening system were found and classified according to the four domains of co-parenting. Feature requirements of co-parenting strengthening system are presented in Table I.

The development of cloud-based co-parenting strengthening system at an early stage has four main features: (1) child's activity scheduling and reminder; (2) co-parenting's education contents; (3) partner's feedback; and (4) co-parenting's assessment.

Based on the requirement analysis above and the need to fulfill the features of the system to be built, a new model in co-parenting is created that undergoes technological interference to improve the quality of coparenting between couples. Of course, this built model really considers the four domains of co-parenting as a measuring tool to see the work effectiveness of a technology intervention in co-parenting. We call the system to be built under the name DUET. Suggested cloud-based co-parenting strengthening system is presented in Fig. 2.

The system design uses a Unified Modelling Language (UML) diagram which serves to describe the work process of the application. At this stage, the UML diagram used is a use case diagram that describes typical interactions between system users and the system itself and provides a narrative about how the system is used [23]. Use case diagram is presented in Fig. 3.

TABLE I

FEATURE REQUIREMENTS OF CO-PARENTING STRENGTHENING SYSTEM

\begin{tabular}{lcccc}
\hline \multirow{2}{*}{ Features } & \multicolumn{3}{c}{ Domains of Co-Parenting } \\
\cline { 2 - 5 } & $\begin{array}{c}\text { Child Rearing } \\
\text { Agreement }\end{array}$ & $\begin{array}{c}\text { Support/ } \\
\text { Undermining }\end{array}$ & $\begin{array}{c}\text { Joint Family } \\
\text { Management }\end{array}$ & $\begin{array}{c}\text { Division of } \\
\text { Labor }\end{array}$ \\
\hline Child's activity scheduling and reminder & $\sqrt{ }$ & $\sqrt{ }$ & $\sqrt{ }$ \\
Contents of co-parenting's education & $\sqrt{ }$ & $\sqrt{ }$ & $\sqrt{ }$ \\
Rating and comment as partner's feedback & & $\sqrt{ }$ & $\sqrt{ }$ \\
Co-parenting's assessment & $\sqrt{ }$ & & $\sqrt{ }$ \\
\hline
\end{tabular}




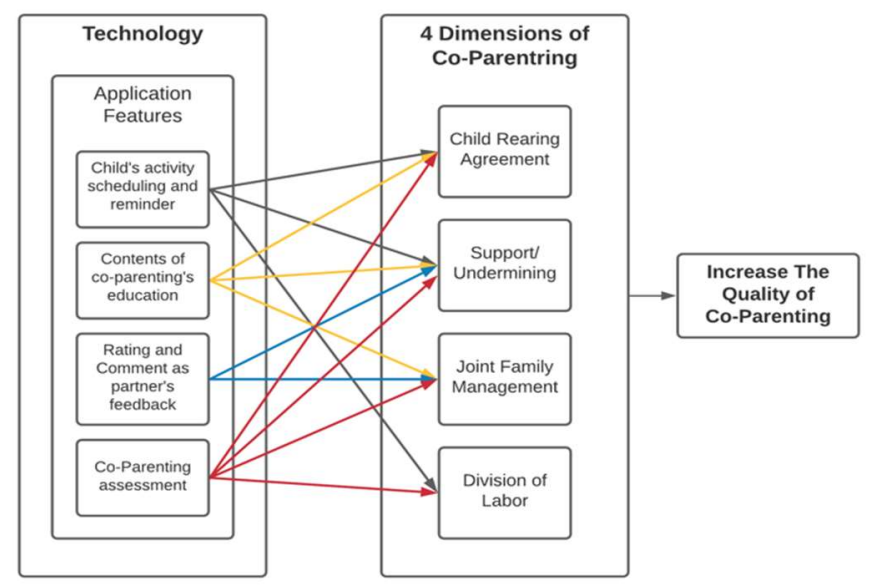

Fig. 2 Cloud-based co-parenting strengthening system model

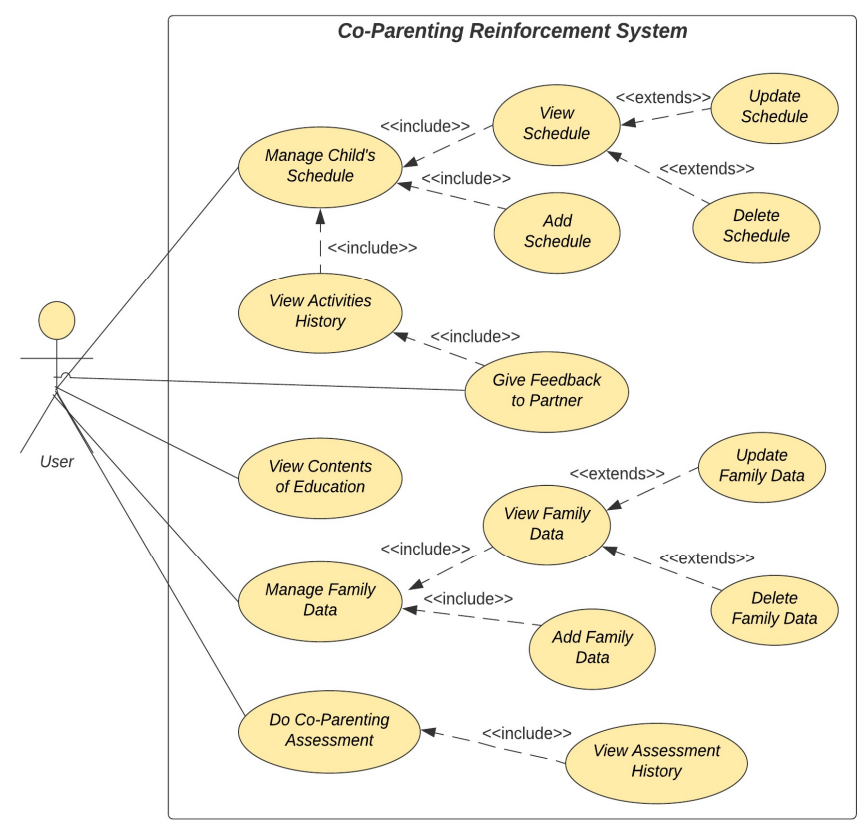

Fig. 3 Use case diagram of cloud-based co-parenting strengthening system

Fig. 3 in use case diagram, user can manage child's schedule, give feedback to partner as appreciation, view

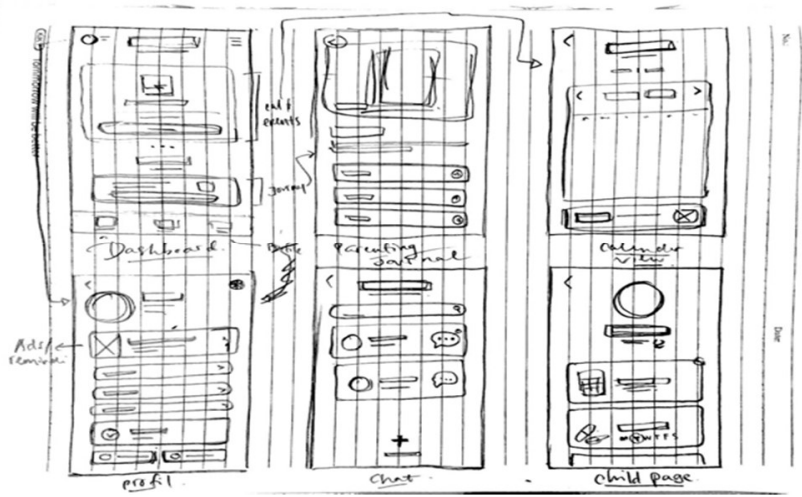

contents of education, manage family data, and do coparenting assessment.

The system architecture is created to provide an overview of the conceptual model of the structure, behavior, and view of the cloud-based co-parenting strengthening system. System Architecture is presented in Fig. 4.

Fig. 4 in system architecture, it divided into two sides, namely the client side and the server side. On the client side, there is an android-based mobile application that can be accessed by users who in this case are married couples, and a website application that can be accessed by admins to manage master data from the system built. The client side can communicate with the server using an internet connection by sending a request body in the form of JSON. On the server side, an API service is built that will mediate communication between the application on the client side and the database on the cloud server. The backend environment is built with PHP framework, JavaScript and SQL as database. The server will return the response body in the form of JSON.

Next step is the wireframing process, where wireframing emphasizes low-fidelity designs with a low level of precision in design components [24]. Wireframing is done using hand sketches on paper. Wireframe designs are presented in Fig. 5.

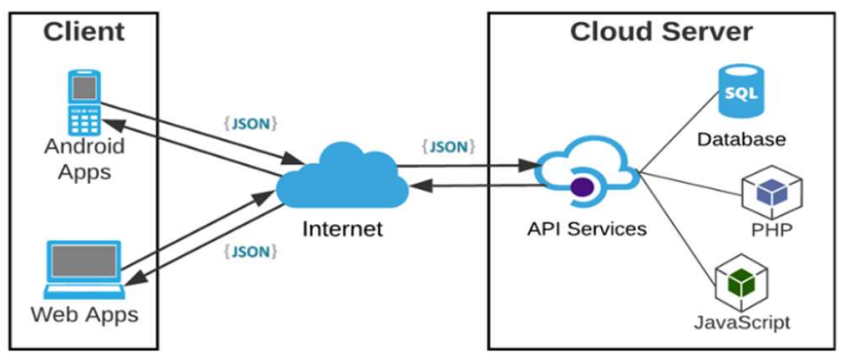

Fig. 4 System architecture of cloud-based co-parenting strengthening system

Fig. 5 Wireframe design of mobile application 
After wire framing, next phase is implementation of cloud-based co-parenting strengthening system. Mobile application is divided into three main sections, namely introduction page, authentication page and user page. Introduction page consists of welcoming page and on boarding page. Authentication page consists of login page and register pages. Lastly, user's main menu consists of dashboard menu, education menu and account or user's profile menu. The details implementation of mobile application pages can be shown in Table II.
Based on Table II of the mobile application pages implementation, the introduction section can be shown in Fig. 6, the authentication section can be shown in Fig. 7 , and the user's main menu section can be shown in Fig. 8.

After the implementation done, black-box testing is carried out using several Android devices with a minimum system requirement of Android OS version 6.0. The black-box testing results are presented in Table III.

TABLE II

MOBILE APPLICATION PAGES IMPLEMENTATION

\begin{tabular}{|c|c|c|}
\hline Sections & Pages & Description \\
\hline \multirow[t]{2}{*}{ Introduction Page } & Welcoming Page & Very first screen that shown when we open Duet application. \\
\hline & On Boarding Page & $\begin{array}{l}\text { Pages inside one adapter with the process of acquainting a new } \\
\text { user with Duet application. }\end{array}$ \\
\hline \multirow[t]{2}{*}{ Authentication Page } & Login Page & $\begin{array}{l}\text { A page where user can login into Duet application to use the } \\
\text { services. }\end{array}$ \\
\hline & Register Page & $\begin{array}{l}\text { A page where user can fill the registration form to register into } \\
\text { Duet application. }\end{array}$ \\
\hline \multirow[t]{3}{*}{ User's Main Menu } & Dashboard Menu & $\begin{array}{l}\text { Dashboard menu consists of calendar, reminder to do the last co- } \\
\text { parenting assessment and the newest education contents } \\
\text { published. }\end{array}$ \\
\hline & Education Menu & $\begin{array}{l}\text { Education menu consists of content list such as tips and tricks, } \\
\text { education, and information related to co-parenting. }\end{array}$ \\
\hline & Account Menu & $\begin{array}{l}\text { Account menu consists of personal information, family } \\
\text { information, faq, and additional function related to user's account. }\end{array}$ \\
\hline
\end{tabular}

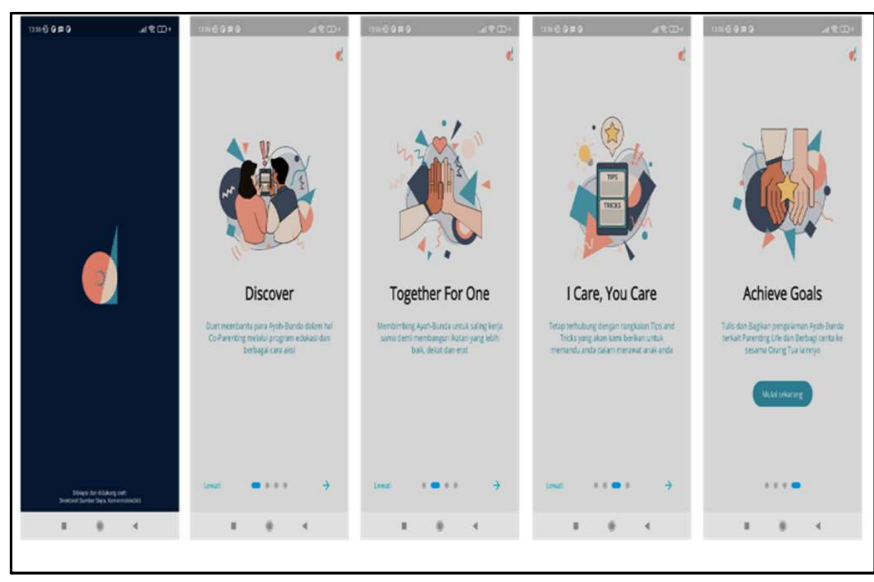

Fig. 6 Introduction section of mobile application

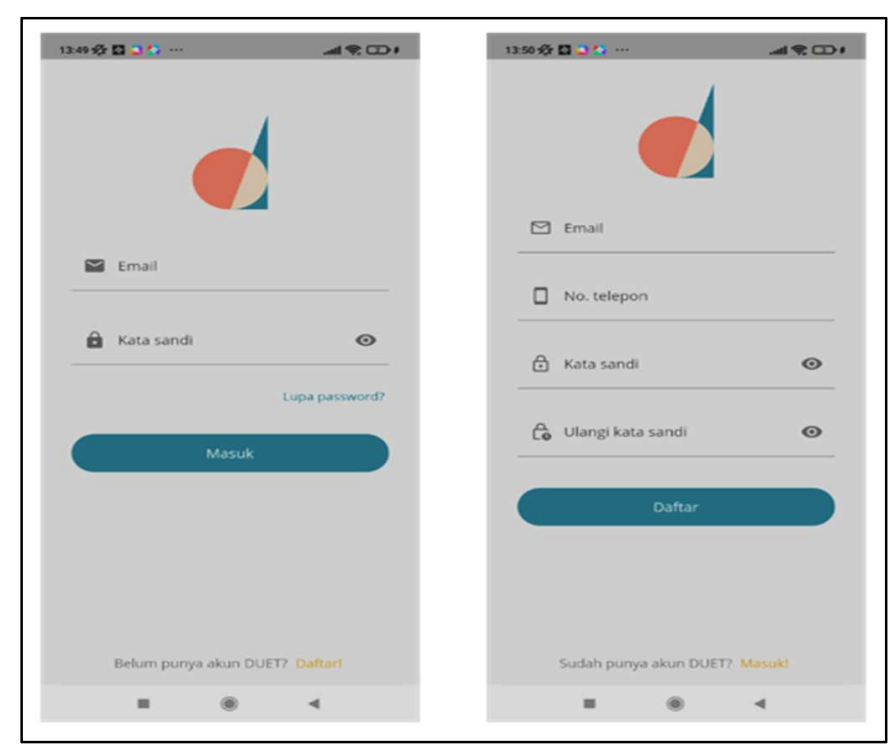

Fig. 7 Authentication section of mobile application 


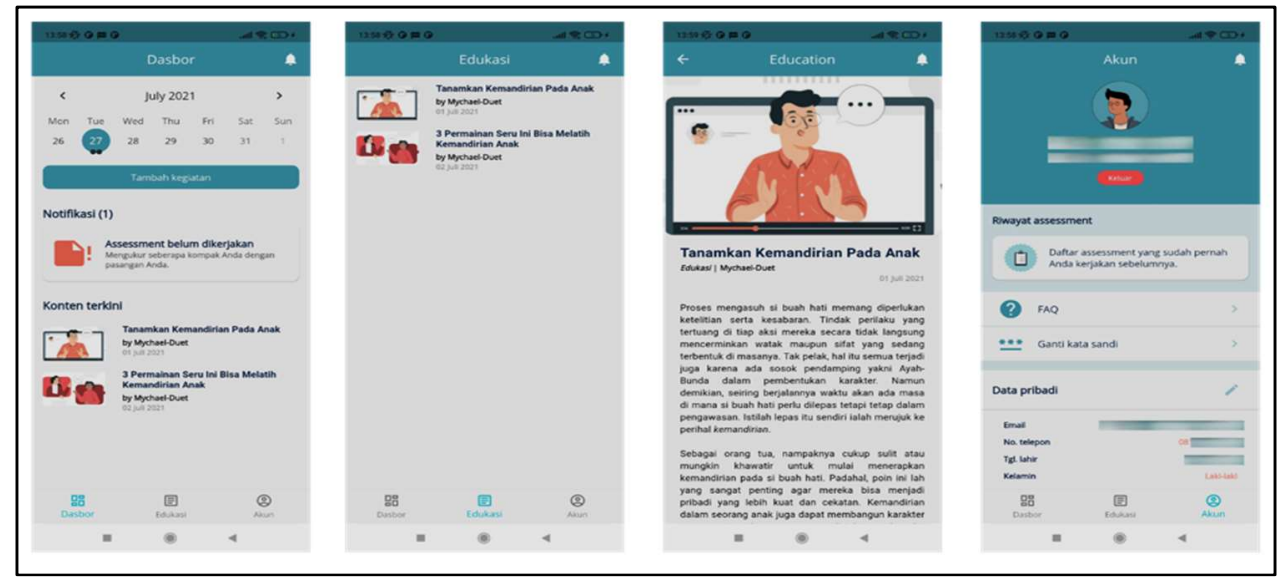

Fig. 8 User's main menu section of mobile application

TABLE III

FUNCTIONALITY (BLACK-BOX) TESTING

\begin{tabular}{|c|c|c|c|c|c|}
\hline No & Tested Function & Condition & Expected Result & Actual Result & Status \\
\hline 1 & Splashscreen & User opens the application & $\begin{array}{l}\text { After loading is } \\
\text { complete, enter on } \\
\text { boarding page }\end{array}$ & $\begin{array}{l}\text { After loading is } \\
\text { complete, enter on } \\
\text { boarding page }\end{array}$ & Valid \\
\hline \multirow[t]{3}{*}{2} & Register & $\begin{array}{l}\text { User lets one or more fields } \\
\text { empty }\end{array}$ & Registration failed & Registration failed & Valid \\
\hline & & User registers with same email & Registration failed & Registration failed & Valid \\
\hline & & $\begin{array}{l}\text { User fills the registration form } \\
\text { correctly }\end{array}$ & $\begin{array}{l}\text { Registration success } \\
\text { and user receive } \\
\text { verification email }\end{array}$ & $\begin{array}{l}\text { Registration success } \\
\text { and user receive } \\
\text { verification email }\end{array}$ & Valid \\
\hline \multirow[t]{2}{*}{3} & Login & $\begin{array}{l}\text { User fills the wrong email and } \\
\text { password }\end{array}$ & Login failed & Login failed & Valid \\
\hline & & $\begin{array}{l}\text { User fills the right email and } \\
\text { password }\end{array}$ & Login success & Login success & Valid \\
\hline \multirow[t]{3}{*}{4} & Child's Schedule & $\begin{array}{l}\text { User set new schedule on the } \\
\text { right way }\end{array}$ & $\begin{array}{l}\text { Scheduled and } \\
\text { reminder ringing on } \\
\text { time }\end{array}$ & $\begin{array}{l}\text { Scheduled and } \\
\text { reminder ringing on } \\
\text { time }\end{array}$ & Valid \\
\hline & & $\begin{array}{l}\text { User has not submitted } \\
\text { feedbacks }\end{array}$ & $\begin{array}{l}\text { Feedbacks from partner } \\
\text { is still empty }\end{array}$ & $\begin{array}{l}\text { Feedbacks from partner } \\
\text { is still empty }\end{array}$ & Valid \\
\hline & & User has submitted feedbacks & Feedback is available & Feedback is available & Valid \\
\hline \multirow[t]{2}{*}{5} & $\begin{array}{l}\text { Education } \\
\text { Contents }\end{array}$ & No contents data in database & $\begin{array}{l}\text { There is no data to } \\
\text { show }\end{array}$ & $\begin{array}{l}\text { There is no data to } \\
\text { show }\end{array}$ & Valid \\
\hline & & Data is available in database & Shows list of contents & Shows list of contents & Valid \\
\hline \multirow[t]{2}{*}{6} & $\begin{array}{l}\text { Co-Parenting } \\
\text { Assessment }\end{array}$ & $\begin{array}{l}\text { User lets one or more question } \\
\text { items empty }\end{array}$ & $\begin{array}{l}\text { Assessment failed to } \\
\text { submit }\end{array}$ & $\begin{array}{l}\text { Assessment failed to } \\
\text { submit }\end{array}$ & Valid \\
\hline & & $\begin{array}{l}\text { User finish the question } \\
\text { correctly }\end{array}$ & $\begin{array}{l}\text { Assessment success to } \\
\text { submit }\end{array}$ & $\begin{array}{l}\text { Assessment success to } \\
\text { submit }\end{array}$ & Valid \\
\hline 7 & User's Account & $\begin{array}{l}\text { User fills the same data when } \\
\text { update account }\end{array}$ & Data is not change & Data is not change & Valid \\
\hline \multirow[t]{2}{*}{8} & Reset Password & $\begin{array}{l}\text { User input the wrong old } \\
\text { password }\end{array}$ & Reset password failed & Reset password failed & Valid \\
\hline & & $\begin{array}{l}\text { User input the correct old } \\
\text { password }\end{array}$ & Reset password success & Reset password success & Valid \\
\hline \multirow[t]{2}{*}{9} & Logout & $\begin{array}{l}\text { Press button logout and } \\
\text { choose cancel option }\end{array}$ & Logout failed & Logout failed & Valid \\
\hline & & $\begin{array}{l}\text { Press button logout and } \\
\text { choose ok option }\end{array}$ & $\begin{array}{l}\text { Logout success, user } \\
\text { goes back to login page }\end{array}$ & $\begin{array}{l}\text { Logout success, user } \\
\text { goes back to login page }\end{array}$ & Valid \\
\hline
\end{tabular}


Based on Table III, it can be seen that the test status of each function is valid. The process of input from user and output produced by system is as expected. It can be concluded that this application has been running well as expected in functionality.

Furthermore, beta testing was carried out to the three experts in their respective fields as early adopters of the system that had been developed. The Likert scale method was used to measure several questions posed to experts from the fields of psychology, UI/UX design and technology. The Likert scale is divided into 5 levels, namely 1 to 5 for each question. Next, the final result is determined from the number of points obtained from expert assessments in each field then divided by the maximum number of scores and multiplied by $100 \%$.
The interval value of each level is $20 \%$. The Likert scale is presented in Table IV. Then, the data obtained from the results of validation and interviews with experts have been processed and presented in Table $\mathrm{V}$.

TABLE IV

LIKERT SCALE

\begin{tabular}{ccc}
\hline Answer & Value & Percentage (\%) \\
\hline Very Good & 5 & $81-100$ \\
Good & 4 & $61-80$ \\
Average & 3 & $41-60$ \\
Poor & 2 & $21-40$ \\
Very Poor & 1 & $0-20$ \\
\hline
\end{tabular}

TABLE V

RESULTS OF BETA TESTING

\begin{tabular}{|c|c|c|c|}
\hline Questions & Score & Percentage & Category \\
\hline Psychology & & \multirow{6}{*}{$76,00 \%$} & \multirow{6}{*}{ Good } \\
\hline $\begin{array}{l}\text { Are the articles in this application useful for fathers and mothers in } \\
\text { parenting? }\end{array}$ & 4 & & \\
\hline $\begin{array}{l}\text { Are the articles in this application useful for fathers and mothers in } \\
\text { coordinating and nurturing cooperation? }\end{array}$ & 3 & & \\
\hline Are the articles in this application easy for users to understand? & 2 & & \\
\hline $\begin{array}{l}\text { Are notifications in this application useful to facilitate coordination and } \\
\text { cooperation in parenting? }\end{array}$ & 5 & & \\
\hline $\begin{array}{l}\text { Is the calendar in this application useful for facilitating childcare } \\
\text { coordination and cooperation? }\end{array}$ & 5 & & \\
\hline \multicolumn{4}{|l|}{ UI/UX Design } \\
\hline Does the application have an attractive design? & 5 & \multirow{7}{*}{$94,28 \%$} & \multirow{7}{*}{ Excellent } \\
\hline Is the choice of color palette used very suitable for the target user? & 5 & & \\
\hline Is the layout of the content in the application good and easy to read? & 5 & & \\
\hline Is the illustration style used in accordance with the target user? & 4 & & \\
\hline $\begin{array}{l}\text { Are the features in the application very useful to meet the needs of co- } \\
\text { parenting? }\end{array}$ & 4 & & \\
\hline $\begin{array}{l}\text { Can the icons used provide clear instructions for the user to access the } \\
\text { application? }\end{array}$ & 5 & & \\
\hline Overall, the application has an easy-to-use interface. & 5 & & \\
\hline \multicolumn{4}{|l|}{ Technology } \\
\hline $\begin{array}{l}\text { Does the application have an effective and efficient system in } \\
\text { development? }\end{array}$ & 5 & \multirow{6}{*}{$90,00 \%$} & \multirow{6}{*}{ Excellent } \\
\hline Does the application have an effective and efficient system in use? & 5 & & \\
\hline Does the application use the latest technology? & 4 & & \\
\hline Does the application have a reliable system architecture? & 5 & & \\
\hline $\begin{array}{l}\text { Does the application have a flexible system architecture and allows for } \\
\text { further development? }\end{array}$ & 4 & & \\
\hline The application can be managed/ maintained easily. & 4 & & \\
\hline
\end{tabular}




\section{CONCLUSION}

Based on the results and discussions, it can be concluded that the development of cloud-based coparenting strengthening system answered the needs of co-parenting between married couples. It is proven by experts who agree that educational content in the application is very necessary for more knowledge for parents, UI/UX design that is friendly and easy to understand by users, as well as the use of the latest reliable and flexible technology. The features in the application, such as giving a rating and feedback on partner's parenting, are considered very important in the journal of appreciation. Likewise, the scheduling feature on the calendar is useful for facilitating coordination and cooperation between married couples in co-parenting. For the next development of wearable devices, it is a very possible integration opportunity for this application. Where, by ensuring that our applications can be run on devices that are used daily such as watches will increase the level of application usage. In addition, wearable devices provide an opportunity for comprehensive recording of children's activities automatically without bothering the users.

\section{ACKNOWLEDGEMENT}

Thanks to the Directorate of Resources, Directorate General of Higher Education, Ministry of Education, Culture, Research and Technology for the opportunity and funding support for The Leading University Applied Research (PTUPT) scheme for the Fiscal Year 2021.

\section{REFERENCES}

[1] BKKBN, "Rencana Strategis BKKBN 2020-2024”, pp. 1-71, 2020.

[2] M. E. Feinberg, M. L. Kan, and E. M. Hetherington, "The Longitudinal Influence of Coparenting Conflict on Parental Negativity and Adolescent Maladjustment", Journal of Marriage and Family, 69(3), 687-702, 2007.

[3] M. E. Feinberg, D. E. Jones, M. E. Roettger, A. Solmeyer, and M. L. Hostetler, "Long-term follow-up of a randomized trial of family foundations: Effects on children's emotional, behavioral, and school adjustment," Journal of Family Psychology, vol. 28, no. 6, pp. 821-831, Dec. 2014.

[4] M. E. Feinberg, L. D. Brown, and M. L. Kan, "A MultiDomain Self-Report Measure of Coparenting," Parenting, vol. 12, no. 1, pp. 1-21, Jan. 2012.

[5] J. P. McHale, R. Kuersten-Hogan, and N. Rao, "Growingpoints for coparenting theory and research," Journal of Adult Development, vol. 11, no. 3, pp. 221-
234, Jul. 2004.

[6] L. Elyana and Y. Utanto, "The development of parenting digital multimedia as an educational technology product to support early childhood learning process," in Journal of Physics: Conference Series, vol. 1387, no. 1, Dec. 2019.

[7] A. Bhargava, M. Bhargava, T. Pande, R. Rao, and M. Parmar, "N-TB: A mobile-based application to simplify nutritional assessment, counseling and care of patients with tuberculosis in India," Indian Journal of Tuberculosis, vol. 66, no. 1, pp. 193-196, Jan. 2019.

[8] D. P. Y. Ardiana, I. D. M. A. B. Joni, and I. P. A. E. D. Udayana, "Mobile based chatbot application for HIV/AIDS counseling using artificial intelligence markup language approach," in Journal of Physics: Conference Series, vol. 1469, no. 1, Feb. 2020.

[9] A. E. Budianto, A. Aziz, and N. Hidayah, "ICT application in cyber counseling as a teacher accelerator with optimizing WhatsApp based mobile computing," in Journal of Physics: Conference Series, vol. 1375, no. 1, Nov. 2019.

[10] J. Daan, E. Universitas, and K. S. Wacana, "Model Logo Konseling Dengan Pendekatan Feminis Menyikapi Harga Diri Spiritual Rendah Perempuan Korban Perdagangan Orang”, 2019.

[11] R. I. Vogel et al., "A patient-centered mobile health application to motivate use of genetic counseling among women with ovarian cancer: A pilot randomized controlled trial," Gynecologic Oncology, vol. 153, no. 1, pp. 100-107, Apr. 2019.

[12] J. M. Flujas-Contreras, A. García-Palacios, and I. Gómez, "Technology-based parenting interventions for children's physical and psychological health: A systematic review and meta-analysis," Psychological Medicine, vol. 49, no. 11. Cambridge University Press, pp. 1787-1798, Aug. 01, 2019.

[13] A. Hansen, G. Broomfield, and M. B. H. Yap, "A systematic review of technology-assisted parenting programs for mental health problems in youth aged 018 years: Applicability to underserved Australian communities," in Australian Journal of Psychology, vol. 71, no. 4, pp. 433-462, Dec. 2019.

[14] E. Isis, A. Amini, S. Mujahidin, and F. Syahrawati, "eParenting Consulting in Early Childhood Institution," 2020.

[15] R. S. Pressman, Rekayasa Perangkat Lunak - Buku Satu, 7th ed. Yogyakarta: Andi, 2012.

[16] EllisLab, “CodeIgniter," https://codeigniter.com. [Online] [Accessed: 18-Jun2018].

[17] R. Foster, CodeIgniter web application blueprints: develop full-featured dynamic web applications using the powerful Codelgniter MVC framework, United Kingdom: PACKT, 2015. 
[18] K. Suzuki and M. Whitney, "CodeIgniter Testing Guide”, https://twitter.com/search?q=\#CITestGuide 2015. [Online]. [Accessed: 19-Jun-2021].

[19] Google, "Flutter", https://flutter.dev. [Online]. [Accessed:19-Jun-2021]

[20] A. Biessek and an O. M. Company. Safari, Flutter for Beginners, 2019.

[21] Napoli, Marco L., Beginning Flutter: A Hands On Guide To App Development, Indianapolis: Indiana, John Wiley \& Sons, 2020.
[22] G. O'regan, 'Undergraduate Topics in Computer Science". Mallow, Cork, Ireland: Springer, : http://www.springer.com/series/7592, 2019. [Online]. [Accessed: 26-Jun-2021].

[23] B. Unhelkar, Software Engineering with UML. New York: CRC Press, 2018.

[24] M. J. Hamm, Wireframing essentials: an introduction to user experience design: learn the fundamentals of designing the user experience for applications and websites. United Kingdom: PACKT, 2014. 
JUITA: Jurnal Informatika e-ISSN: 2579-8901; Vol. 9, No. 2, November 2021 